\title{
National Health Insurance: An Idea Whose Time Has Come?
}

\author{
By Sylvester E. Berki
}

\begin{abstract}
Private and public health insurance programs by their selectivity of coverage and means of payment add to the fragmentation and inefficiencies of the health care sector. The proposals for the establishment of some form of national health insurance presented in the more than forty bills before Congress incorporate a wide range of approaches to financing, benefits, accountability, and regulation. This paper elucidates the key policy variables in terms of whose dimensions the different proposals may be analyzed, and some criteria for evaluating their different aspects. The three major proposals-by the Nixon Administration, Senator Edward Kennedy, and the American Medical Association-are detailed and their probable effects discussed. The choice is not between financing mechanisms as such but rather between different systems for providing medical care. Although none of the proposed plans would assure equal access to needed care for all, the Kennedy Plan goes furthest in that direction.
\end{abstract}

Sylvester E. Berki is Associate Professor in the Department of Medical Care Organization, School of Public Health, the University of Michigan, Ann Arbor. He received his undergraduate education at Columbia and did graduate work in Economics at Yale. His monograph, Hospital Economics, will be published in 1972. 
Whether poor or not, most Americans are badly served by the obsolete, over-strained medical system that has grown up around them, helterskelter, without accommodating very well to changing technology, expanding population, rising costs, or rising expectations....

\section{Fortune magazine ${ }^{1}$}

$\mathrm{I}^{\mathrm{N}}$ THE CIVILIAN population, about 81 percent of all individuals under the age of 65 are covered by one or more health insurance plans issued by private companies. Those over 65 are, by and large, eligible for public insurance benefits under the provisions of Medicare, although 50 percent have some form of supplemental private coverage. Coverage by type of service for which the insurance pays the benefits of the under65 group, the focus of public policy, varies greatly. Thus, while 81 percent have hospital benefits, 43 percent have some physician office and home visit benefits, and less than 5 percent have insurance covering dental care. ${ }^{2}$

Private as well as public insurance is not designed to meet the total cost of the services for which it is written. Deductible amounts and co-payments are incorporated in most policies. ${ }^{3}$

In fiscal year 1970, the latest period for which data are available, of the total national health expenditures of $\$ 67$

1. Anonymous editorial, "It's Time To Operate," Fortune 81, 1 (January, 1970), p. 79.

2. Marjorie Smith Mueller, "Private Health Insurance in 1969: A Review," Social Security Bulletin 34, 2 (February, 1971), p. 4.

3. A deductible amount is an amount in dollars that the beneficiary must pay out of pocket before the benefits take effect. A co-payment, often euphemistically called coinsurance, is an amount expressed as a percentage of total costs that the beneficiary has to pay out of pocket. Thus, a policy with a $\$ 50$ deductible and 20 percent co-payment will pay 80 percent of the cost of services covered after the first $\$ 50$ expenditure by the beneficiary. Policies also usually have upper dollar or specific service limitations per period of time. billion, 63 percent, or $\$ 42$ billion, were outlays by the private sector for direct payments for services, health insurance premiums, construction of medical facilities, and research. ${ }^{4}$ Expenditures for personal health care, excluding construction and research, were $\$ 58$ billion, of which $\$ 37.5$ billion were private outlays. Direct payment for services and for insurance costs amounted to $\$ 23$ billion, or 61 percent. Private insurance benefits were $\$ 14$ billion, about 39 percent of private expenditures. ${ }^{5}$

Gaps in coverage, together with the effects of co-payments and deductibles, resulted in uneven benefit payments. Thus, 30 percent of private hospital expenses, 57 percent of physician expenses, and 95 percent of other health care costs, including dental, optometric, prescription, and nursing home services, were not met by insurance payments and were paid for directly by the individuals concerned. ${ }^{6}$

The current health insurance system introduces two basic forms of distortion to the provision of medical care services. In situations when medically considered appropriate services may be provided in alternative ways, both the patient and the physicians are likely to choose the way covered by insurance, whether or not that is economically efficient. Selective insurance reduces the relative price facing the patient and assures payment to the physician of the set of covered services, whether alternatives exist or not. Thus, for those who have hospital coverage but not ambulatory benefits, it is less costly to be hospitalized for a sequence of diagnostic $x$-rays and laboratory work even though the services could be equally well provided

4. Dorothy P. Rice and Barbara S. Cooper, "National Health Expenditures, 1929-1970," Social Security Bulletin 34, 1 (January, 1971), p. 5 .

5. Ibid., p. 15.

6. Mueller, op. cit., p. 18. 
at significantly lower cost on an ambulatory basis. ${ }^{7}$ The insurance mechanism itself, therefore, offers an inducement for an inefficient use of resources because of its selectivity.

Inefficiencies and cost escalation are also invited by the form in which benefits are paid. With extremely few exceptions, health insurance plans are written to pay the provider of service on a "cost plus" basis: hospitals are reimbursed for "reasonable costs" of providing care, and physicians at "usual and prevailing" charges. The providers, therefore, not only have no incentives to choose efficient and less costly ways of supplying care but, on the contrary, are indirectly encouraged to use resourceintensive processes and to charge what the market will bear. Further, since the insurance carriers have rarely engaged in cost control and the patient pays the premium, the providers are in the best of possible economic worlds: I call the tune and you pay the piper. The attempt to eliminate these distortions has been an important factor in the development of prepaid group practices, which for prepayment on a per capita basis agree to provide a comprehensive set of medically useful services to their members. $^{8}$

Selective private health insurance is both a part of the "helter-skelter" medical care sector and a collective private

7. This price-distorting effect of selective health insurance has been much discussed in terms of "moral hazard." See Kenneth J. Arrow, "Uncertainty and the Welfare Economics of Medical Care," American Economic Review, December, 1963, p. 941, and "Comments" by Pauly and Arrow, loc. cit., June, 1968 , p. 531.

8. See, for example, "Group Practice: Problems and Perspectives," Bulletin of the New York Academy of Medicine 44, 11 (November, 1968), pp. 1277-1434. For a critical economic evaluation see Herbert E. Klarman, "Approaches to Moderating the Increases in Medical Care Costs," Medical Care 7, 3 (MayJune, 1969), pp. 175, 179-184. system to finance at least some of the costs without disturbing any of the present relationships. National Health Insurance is a public system for the collective financing of privately provided services incorporating different degrees of public planning and control.

\section{Some History and Some Problems}

The gestation period of this idea whose time seems to have arrived is much longer than it would appear. Commissions to study the feasibility of social health insurance were established in several states as early as 1910 to 1915 , to the general approbation of the American Medical Association (AMA), which in 1915 noted:

The failure of many persons in this country at present to receive medical care constitutes the best argument for a change to the more effectual provision of medical attention offered by health insurance. ${ }^{9}$

With attention diverted from social legislation by the First World War, followed by the euphoria of the Roaring Twenties, it was not until 1932 that the issue was resurrected by the Committee on Medical Care recommendation for substantial changes in the system. The Minority Report prepared by representatives of the AMA was opposed to any national system but argued:

To recommend that our own country again experiment with discredited methods of voluntary insurance is simply to ignore all that has been learned by costly experience in many other countries as well as our own. ${ }^{10}$

9. Journal of the $A M A$, October $30,1915, \mathrm{p}$. 1560 , quoted in Elton Rayack, Professional Power and American Medicine (Cleveland: World, 1967), p. 138.

10. Medical Care for the American People, Final Report of the Committee on the Costs of Medical Care (adopted October 31, 1932). Reprinted, U.S. Dept. of Health, Education, and Welfare, 1970, Public Health Service, Health Services and Mental Health Administration, Community Health Service, p. 164. 
Therefore, the AMA argument followed, if there is to be national health insurance at all, it should be "a compulsory plan under government control." But the AMA had soon changed its tune to one which still reverberates today:

Some people think that people are entitled to health care as a matter of right, whether they work or not. This is just as absurd as saying that food, clothing and shelter are a matter of right-one step further than that is a revolutionary system bordering on Communism. ... ${ }^{11}$

The active opposition of the nation's physicians, combined with the shift of priorities away from health associated with the Depression and World War II, led to another period of dormancy. It was not until 1943 that this idea conceived thirty-three years previously began to demonstrate some new signs of life with the introduction of the WagnerMurray-Dingell Bill. Since then, not a single session of Congress in the ensuing twenty-nine years has been without the introduction of a bill for some form of national health insurance. ${ }^{12}$

The periodicity of the political history of national health insurance found its reflection in the analytic debate, not to say debatable analyses. The next to the last round was ushered in with the statement: "An examination of the economic issues of compulsory health insurance is today of first importance." ${ }^{13}$

11. Edward R. Annis, M.D., former president of the AMA, quoted in The New York Times, October 14, 1971.

12. For a brief history, see W. J. Cohen, "National Health Insurance-Problems and Prospects," the 1970 Michael M. Davis Lecture, Center for Health Administration Studies, Graduate School of Business, University of Chicago.

13. R. R. Campbell and W. G. Campbell, "Compulsory Health Insurance: The Economic Issues," Quarterly Journal of Economics 66, 1 (February, 1952), p. 1. See also I. S.
That was 1952. It is now 1972, and while the current student may have recourse to some technically enlightening analyses he will find no generally accepted procedures, objectives, or assumptions - except one: that national health insurance will be costly.

The successes of economics flow from the development of sophisticated analytic techniques to derive the not always obvious implications of some rather simple, if strong, assumptions, such as profit maximization as the objective of firms and preference maximization, that of consumers. While it could be shown that private interaction through the market system would lead to an optimal solution of the problem of resource allocation if certain competitive conditions were met-chief among them the use of market-determined competitive prices as allocative signals - it is precisely in the two problem areas characteristic of the medical care sector that economic analysis is weakest. These are the issues of distributional equity and allocational efficiency under circumstances when either the private markets that exist function poorly, or markets as such are unacceptable allocators because of ethical judgments about the circumstances and outcomes.

"Medical care is a right" is the cliche of the year. Judged by the disparity between stated objectives and observed actions, it is hypocrisy as well. Nevertheless, it is both useful and symbolicuseful because it reiterates a desirable objective; symbolic because it recognizes that medical care services cannot and

Falk, "The Economic Issues of Compulsory Health Insurance: Comment," ibid., 66, 4 (November, 1952), pp. 572-591; R. R. Campbell and W. G. Campbell, "The Economic Issues of Compulsory Health Insurance: Reply" ibid., 67, 1 (February, 1953), pp. 125135 ; A. Kemp, "Health Services and Political Economy," Modern Age 7 (Summer, 1963), pp. $255-268$. 
should not be dispensed solely via unconstrained private markets. ${ }^{14}$

One of the principal reasons for doubt about the desirability of market allocation of medical services is also the basic source of difficulty in public policy analysis: if the values of avoiding, limiting, or postponing anxiety, pain, debility, and death are not appropriately reflected in the market-determined fees of medical services, how then do we measure the benefits of public programs? The benefits of any program, be they increased accessibility to providers, more effective preventive care, reduced morbidity and mortality, or, in general, higher levels of health, are extremely difficult to measure even for those who believe that they are not largely independent of the quantity and quality of medical care. ${ }^{15}$ Money costs, on the other hand, are more easily definable and measurable. As a result, the "intangible" benefits tend to be vaguely defined while the analyses in terms of concrete dollar costs march toward their asymmetric conclusions. This basic analytic asymmetry must be borne in mind, for the advocates of comprehensive compulsory national health insurance are not a set of politically masochistic profligates nor professional do-gooders bent on doing-in the AMA. The advocates of national health insurance, like the then ridiculed and now imitated Keynesians of the late 1930's, in fact believe that the way to keep and to improve the desirable elements of the current private system of medical care, while at the same time assuring the availability and accessibility of high

14. See, for instance, Avedis Donabedian, "Social Responsibility for Personal Health Services: An Examination of Basic Values," Inquiry 8, 2 (June, 1971), pp. 3-19.

15. For a different view, see Mark V. Pauly, National Health Insurance: An Analysis, American Enterprise Institute for Public Policy Research. Washington, D.C., August, 1971. quality care at adequate levels to all Americans at reasonable cost, is through the establishment of a national system of financing, planning, and control.

\section{The Dimensions of National Health Insurance}

National health insurance (NHI) schemes run a continuum from compulsory plans providing total health care within a reorganized system to all members of the population, which we might call "Total, Comprehensive, Compulsory" (TCC), to plans designed to provide limited benefits to defined population categories with minor adjustments in the current system, on a voluntary basis, which may be called "Limited, Categorical, Voluntary" (LCV). Some forty bills currently introduced in both Houses of Congress cover the entire spectrum of variability. ${ }^{16}$ They have but three common denominators: (1) a recognition that something is wrong; (2) the acceptance of the insurance principle; and (3) the need for some governmental intervention. That is, the schemes call for one or another version of a financing mechanism to cover the costs of privately provided services and not for the direct provision of medical services by a "national health service." This last is their principal difference from systems in other industrialized countries. ${ }^{17}$

The objectives any plan is designed to attain and the likelihood that it in fact will do so may be laid bare and

16. For a list of bills, see Appendix.

17. For studies of other countries, see $M$. H. Cooper and A. J. Culyer, "An Economic Survey of the Nature and Intent of the British National Health Service" Social Science and Medicine 5, 1 (February, 1971), pp. 1-12; William A. Glaser, Paying the Doctor: Systems of Remuneration and Their Effects (Baltimore: Johns Hopkins Press, 1970) ; Milton I. Roemer, The Organisation of Medical Care Under Social Security (Geneva: International Labour Office, 1969). 
Table 1-Policy Vartables Relevant to National Heatth Insurance Programs

\begin{tabular}{ll}
\hline \multicolumn{1}{c}{ Policy VARtable } & 1) Who is to benefit \\
2) Methods of exclusion \\
3) Methods of inclusion \\
Target Benefit Coverage & 1) What benefits are provided \\
2) What benefits are excluded \\
3) Methods of inclusion of benefits \\
4) Methods of exclusion of benefits \\
Target Utilization & 1) Level of benefits provided \\
2uality Controls & 3) Continuity of benefits \\
Provider Payment & 1) Structure of medical care system specified \\
Financing Mechanism & 2) Medical care process specifications \\
Administrative Mechanism & 1) Methods of appraisal of structure, process and outcome \\
Incentive Mechanism & 1) Methods and bases of revenue collections \\
1) Who administers program
\end{tabular}

analyzed in terms of the dimensions of its policy variables. In Table 1 are presented nine variables subject to manipulation by social policy, and some of their dimensions. ${ }^{18}$

Choice among the plans may be seen to be basically determined by three sets of considerations: (1) socio-political, economic, and ideological criteria relating to the effects of the various policy variables; (2) perceptions of political feasibility; and (3) the evaluation of the present system.

Those who perceive the market system and its outcomes as basically acceptable but in need of improvement for

18. For a detailed discussion and analysis, see Sylvester E. Berki, "Economic Effects of National Health Insurance" Inquiry 8, 2 (June, 1971), pp. $37-55$. certain population groups and in certain "catastrophic" situations, and who wish to limit the role of government while enhancing private decision-making within a pluralistic system, recommend plans of the LCV type. Thus, several plans urging "major risk insurance" or "variable subsidy insurance" or "tax credit insurance" have been proposed by individuals and introduced by representatives of two of the major interest groups involved, the AMA and the insurance carriers. ${ }^{19}$ The Administration's pro-

19. For example, see Martin S. Feldstein, "A New Approach to National Health Insurance," The Public Interest, Spring, 1971, pp. 93-105; Pauly, op. cit.; Charles W. Baird, "A Proposal for Financing the Purchase of Health Services," Journal of Human Resources 5, 1 (Winter, 1970), pp. 89-105; Jeffrey H. Weiss, "A Proposal for Financing 
posal, the "National Health Insurance Partnership Act of 1971," falls into this category. ${ }^{20}$

On the other side are those who see the present system as chaotic and unremediable and who do not believe that uncontrolled private decision-making is possible or desirable. An outstanding critic of some forty years' standing is I. S. Falk, who attributes the present crisis to four basic factors:

1. National shortages in various categories of health manpower and facilities;

2. Steeply rising costs and their financing;

3. Inadequacies in the system for the availability and provision of care; and

4. Lack of sufficient controls for the assurance of quality of care. ${ }^{21}$

Falk specifies the dimensions of policy variables in terms that lead to a plan that would be Total, Comprehensive, and Compulsory. The plan he proposes would provide "all useful and promising medical care services" to the "whole population ... without financial tests or barriers" within a system restructured "on an evolutionary course." In addition, he would require the establishment of fiscal and quality standards, to be enforced through public accountability. ${ }^{22}$ The only bill calling for a plan in this category is the "Health

the Purchase of Health Services: A Comment," Journal of Human Resources 6, 1 (Winter, 1971), pp. 123-124; H.R. 4960, "Health Care Insurance Act" ("Medicredit"), supported by the AMA; H.R. 4349, "National Health Care Act," supported by the Health Insurance Association of America; and see Appendix.

20. H.R. 7741, and S. 1623, see Appendix.

21. I. S. Falk, "National Policies and Programs for the Financing of Medical Care," the 1971 Michael M. Davis Lecture, Center for Health Administration Studies, Graduate School of Business, University of Chicago, p. 4.

22. Ibid., pp. 10-12.
Security Act" introduced by Senator Edward Kennedy. ${ }^{23}$

\section{Criteria for Evaluation}

It is obvious, or should be, that no policy design and no policy result can be evaluated in the absence of criteria that are both relevant and accepted. We suggest eight criteria categories in terms of which the policy variables of NHI proposals may be evaluated. It may be argued that they require information at unattainable levels, and in fact that is one of the prime arguments used to buttress the incrementalist approach to policy formation: if you don't know all the facts, muddle through by meddling. Nonetheless, the introduction of any plan is likely to have significant impacts within each of the categories for which the criteria are proposed, either by changing existing arrangements or by rigidifying them. The criteria for choice may be briefly enumerated:

\section{Institutional Effects:}

How and to what extent do the policy variables affect existing economic, social, and political institutions? What are likely impacts on private markets, on the relationships between the federal/ state/local governmental structures, on voluntarism, and on the work ethic?

\section{Income Distribution Effects:}

How would the distribution of income be affected? What are the income and investment effects of the plan likely to be? What are considered adequate income levels, acceptable and unacceptable cost burdens of beneficiaries? What are the income effects on providers?

\section{Health Distribution Effects:}

How is the plan likely to affect the distribution of health in society, when

23. S. 3, see Appendix. 
health is defined technically by the medical profession as well as by the patient and by social norms?

\section{Production and Allocative Efit- ciency Effects:}

Does the program enhance the use of technically efficient methods to attain its objectives? Do program beneficiaries receive what and how much they in fact desire and what the program envisages? Are induced changes in demands economically "rational" and would they elicit requisite changes in supplies? What are the mechanisms for equilibrating demands and supplies?

\section{Dynamic Effects:}

Is the program likely to stimulate, or to inhibit, innovation? Is it sufficiently flexible to accommodate unforeseen changes in basic parameters of both the medical care system and the larger economy?

\section{Macro Effects:}

What would be the program effects on national economic policies, such as price stabilization? What are desirable private/public mixes, and how would the program affect these? What would be the effects on federal and state tax bases and budgets? What would be the total cost effects?

\section{Benefit Effects:}

Are the methods of providing benefits consistent with social criteria, if they are applicable? For example, are they nondemeaning, or do they require means tests? Is benefit discrimination by income levels acceptable?

\section{Acceptability Effects:}

Are the specified policy variables acceptable to the major groups affected by them? Are the interests of the major interest groups (physicians and other individual providers, hospitals and other institutional providers, insurance carriers, labor unions, and patients) reconciled?

Congressional bills, as one would expect, do not explicitly mention nor refer to many of these criteria. But the title of the act, "National Health Insurance Partnership," (italics added), not to mention its emphasis on the role of private insurance carriers and physician payment on the basis of "reasonable charges" (subject to the limits of retained Medicare provisions), explicitly recognizes the desirability of maintaining the existing system, and within it, the roles of its dominant constituents.

Other proposals assign explicit values to some of the criteria. Assuming that medical care is not basically different from other economic goods, and hence its distribution could best be achieved in a system "which lets consumers decide, on the basis of outcomes, which arrangement they like best," ${ }^{24}$ Pauly makes the traditional free-market argument, recognizing the usually unstated implications in terms of income effects:

Another effect would be to increase the incomes and prices of inputs. In a freely functioning market, the effect of such increases would be, first, to induce existing producers to supply more output and, eventually, to entice more producers into the market. One might not like the fact that existing producers would be earning higher incomes. But the higher incomes are necessary to attract new resources. ${ }^{25}$

Still others are explicit indeed in urging specific criteria by which to evaluate the policy variables of any plan:

24. Pauly, op. cit., p. 16.

25. Ibid., p. 38. Few, if any, analysts would agree either that the medical service markets are "free" in the sense of competitive or that there is a need for, say, additional beds. This is an example of the "as if" fallacy, that is, let's assume the markets would react as if they were free. 
The Medical Committee for Human Rights (MCHR) believes certain principles should underlie any health care in America.

1. All Americans are equally entitled to complete and preventive health care, with no charge at the time of service. Health services should be easily accessible in every community.

2. Health care should be paid for by a progressive national tax on total wealth-m a tax without loopholes that makes the very rich pay their share.

3. No one should gain profit from sickness, misery, and death of others. There should be an end to profit-making in health care.

4. Health care institutions should be locally controlled by representatives of patients and health workers.

5. Race and sex discrimination should be ended for health workers. Minorities, women, and the poor should he justly represented in all health jobs. ${ }^{26}$

Consider now the contours and some of the details of three major plans in terms of the policy variables we have specified.

\section{The Nixon, Kennedy, and Med- CREDIT Plans FOR NHI}

For ease of comparison, in table 2 the dimensions of the policy variables are presented in tabular form. Significant differences in approach become obvious even upon brief inspection of the characteristics of the three major plans.

The Kennedy plan would provide essentially all useful medical services to all the population without regard to income and without the requirement of any direct payment by the patient at the time service is received. Both the Nixon plan and Medicredit require payment at the time of service and treat people at different income levels differently. Medicredit provides fairly comprehensive benefits, except in long-term illness,

26. Preliminary Position Paper on National Health Care (Chicago: The Medical Committee for Human Rights, September, 1971). regardless of the patient's income. But since it is based on tax credit financing, Medicredit does require registration and a means test to qualify for the insurance certificate when the tax liability of the potential beneficiary is zero. Contrary to all available evidence of higher incidence of medical needs at lower income levels, the Nixon plan provides much lower levels of benefits for the poor and the unemployed than for others. ${ }^{27}$ Further, excluding the poor without children, it then establishes no less than 35 income-family size categories for differential benefit coverage and premium payments. To qualify, the family must pass a means test demonstrating income sufficiently low to meet the criteria (welfare payments are included in income) and further, that, other than home, household goods, and personal effects, its resources are below $\$ 1,500$. Once these qualifications have been met and the family members certified eligible, that eligibility is for six months only: each family must be re-examined and recertified every six months. Note that only families with at least one member under the age of $18(22$, if in school) and unmarried, qualify-even if they could pass the means test. ${ }^{28}$

The manner in which services would be utilized and quality standards established is not mentioned by Medicredit at all and only vaguely in the Nixon plan. $^{29}$ Medicredit specifically prohibits

... any Federal officer or employe to exercise any supervision or control over the practice of medicine or the manner in which medical services are provided, over the selection, tenure, or compensation of any officer or employe, or any institution,

27. A. L. Strauss, "Medical Organization, Medical Care and Lower Income Groups," Social Science and Medicine, vol. 3, 1969, pp. 143-177.

28. H.R. 7741, Section 625.

29. H.R. 4960 , Section 2023 


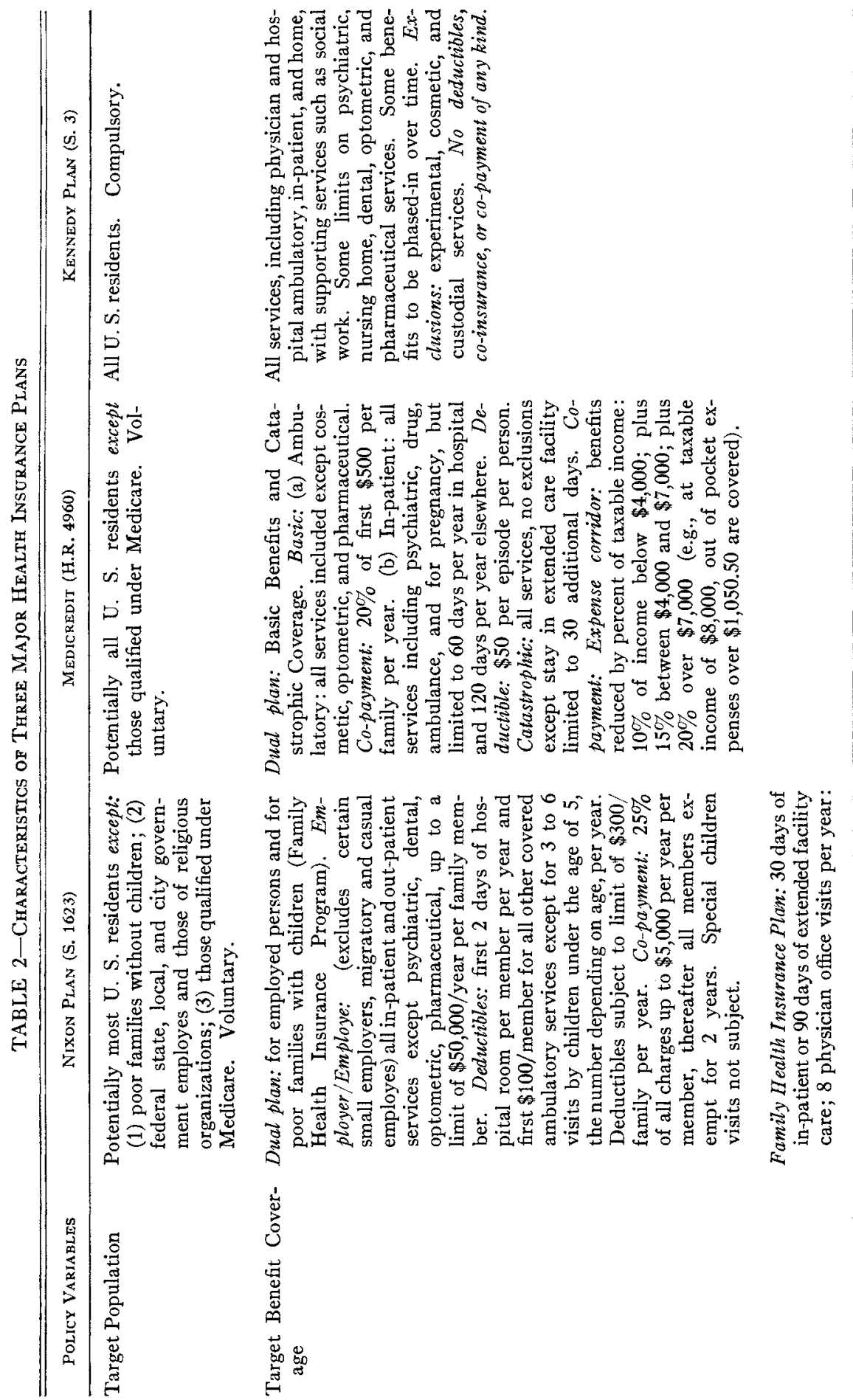




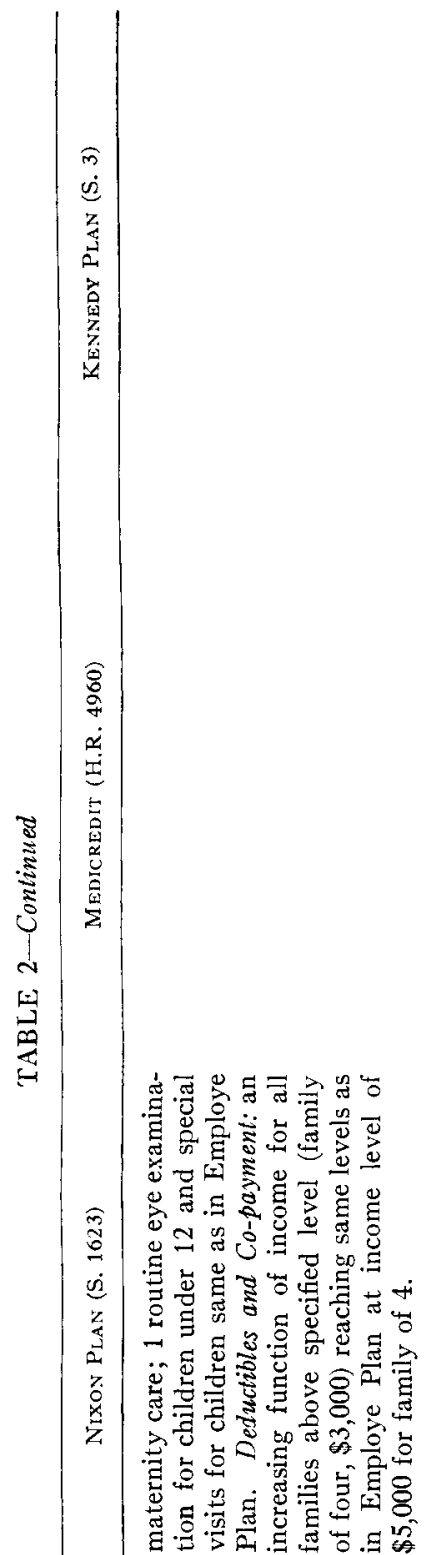

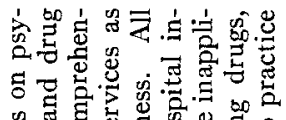

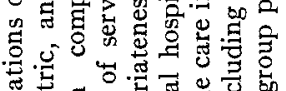
焉 罗

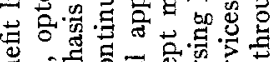

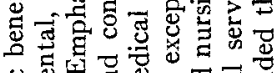

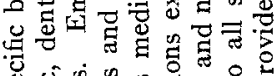

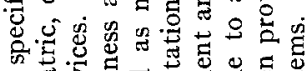

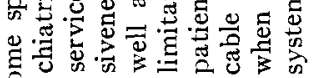
额

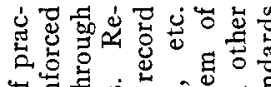

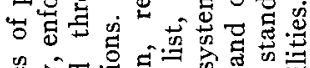

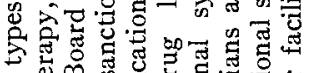

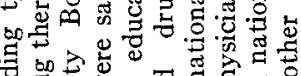

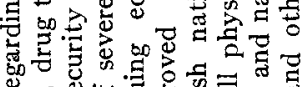

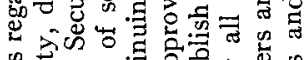

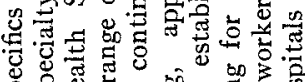

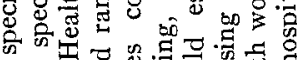

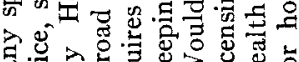

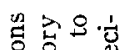

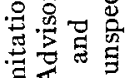
政

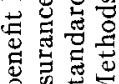

要

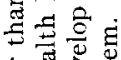

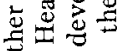

일

政腾

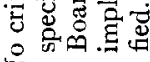
,

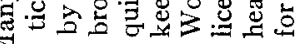

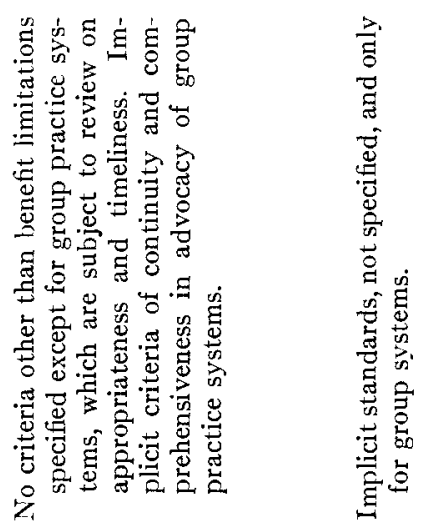

政

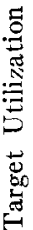




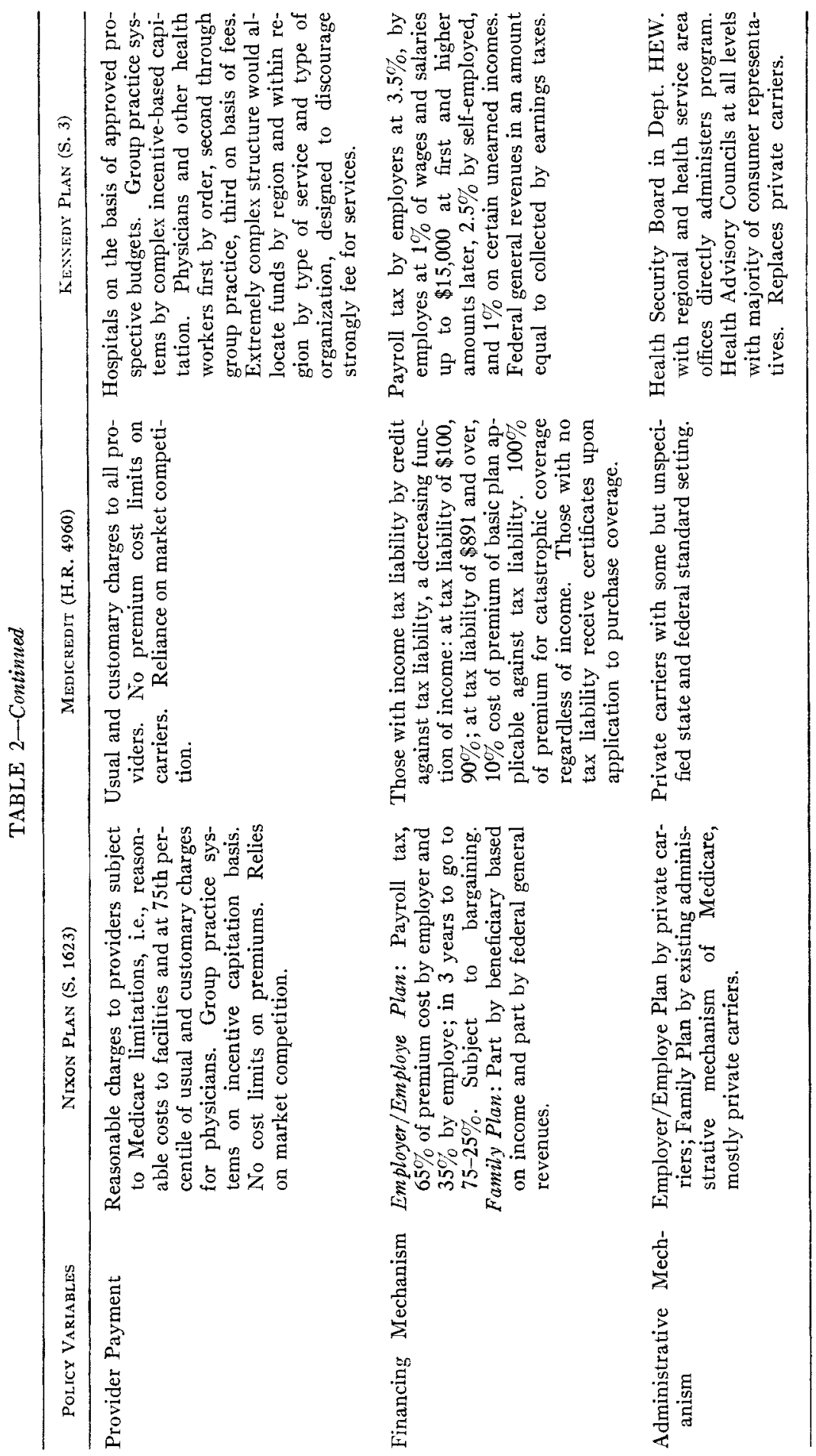




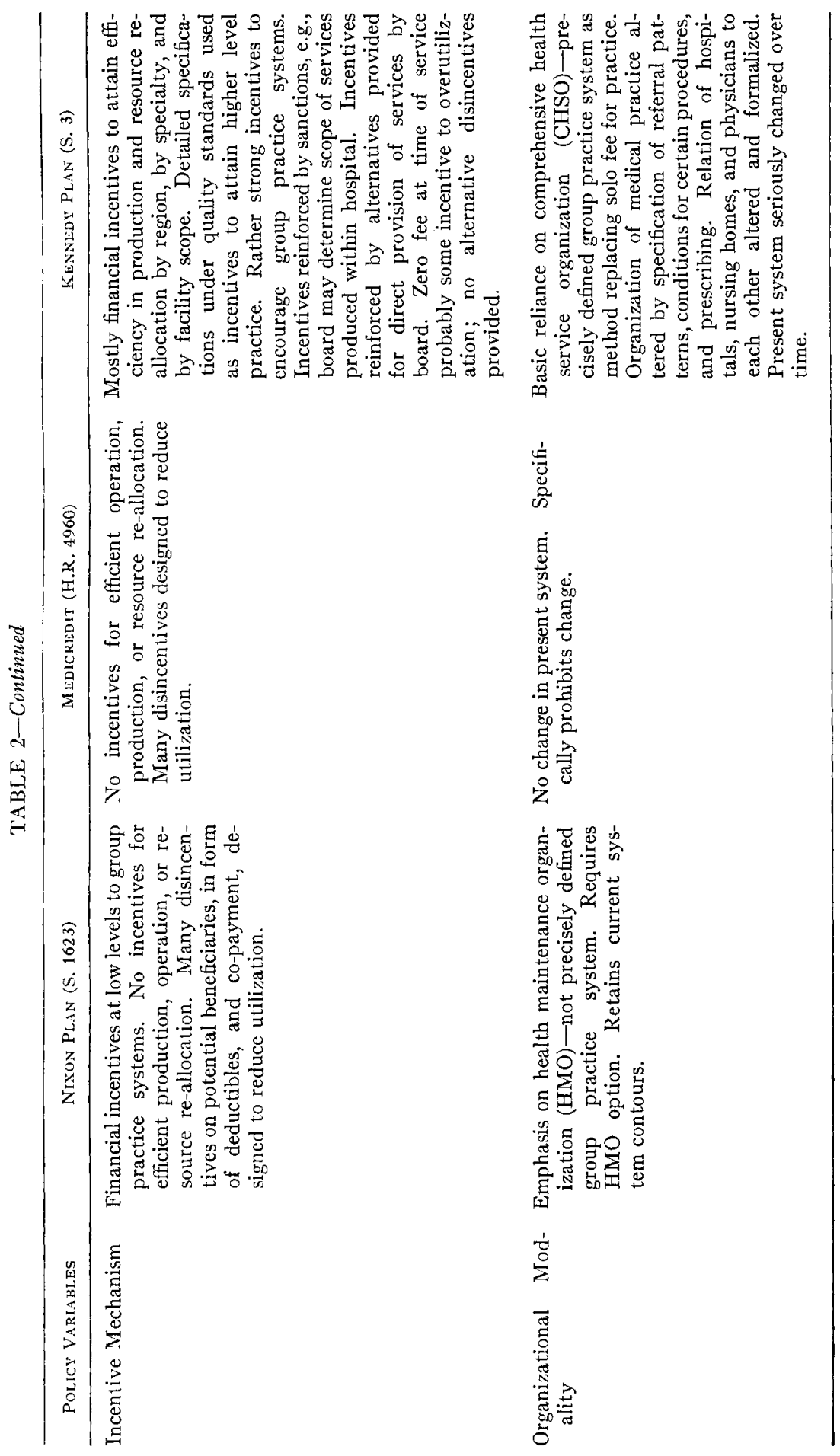


agency, or person providing health services; or to exercise any supervision or control over the administration or operation of any such institution, agency, or person.

While the Nixon Plan relies on the inherent utilization and quality advantages of the HMO, the Kennedy plan goes far in specifying explicit standards of quality and utilization to be enforced by the Health Security Board. ${ }^{30}$ The potential for outside auditing of medical practice by a public body is established. The reliance on public operations is equally evident in the Kennedy plan's specification of the administrative mechanism. Both Medicredit and the Nixon plan rely on private institutions within a market framework, regulated more in the Nixon plan and less in Medicredit. In requiring that all employers with more than one hundred employes make the option of joining an HMO available, the Nixon plan takes several steps in the Kennedy plan's direction-which, by manipulation of the incentive and payment mechanisms, endeavors to make the CHSO the basic provision system for medical services.

Increasing the Health Security Tax base to $\$ 15,000$ from its current Social Security income limit of $\$ 7,800$, imposing a tax on certain unearned and hence presently untaxed incomes, and requiring matching by general revenue funds, the Kennedy plan is potentially much more progressive in its financing mechanism than either of the other plans.

By the use of incentives, sanctions, administrative mechanisms, means of provider payment, and the CHSO, the Kennedy plan envisages a restructured system of coördinated comprehensive services administered on a regional basis. The patchwork approach of the other two plans assumes that the current sys-

30. On the concept of the HMO, see Paul M. Ellwood, Jr. et al, "Health Maintenance Strategy," Medical Care 9, 3 (May-June, 1971), pp. 291-298. tem is workable and that since almost all Americans have some form of health insurance, the best policy is filling the gaps to fit the bill.

\section{Effect of Each Plan on a Family}

Consider the effect of each of these plans on a hypothetical family of four with a gross income of $\$ 6,000$. For purposes of comparison, a rather long period of hospitalization is assumed, precisely to show the differential impacts of the plans under currently pauperizing circumstances. While the Kennedy plan would reduce income by more than either of the two plans in the case of no disease, it would provide much more complete security in case of illness. As can be seen in table 3 , while Medicredit would provide essentially almost complete financial coverage, under the Nixon plan the family's income would be reduced by over $\$ 1,000$, or some 20 percent. And note that this is the result of the cost of services, and not the loss of income resulting from inability to work should the patient be the wage earner.

Even though "progressivity" is built into the Kennedy plan, implying that the increase in income taxes under the plan would be higher than $\$ 100$ at higher income levels, it may be argued that the assumed tax increase is low since the plan would be very costly. John G. Veneman, Undersecretary of the Department of Health, Education, and Welfare, has suggested that the cost of the Kennedy plan in its first full year of operation would be $\$ 77$ billion dollars. ${ }^{31}$ Consider, therefore, the cost estimates provided by HEW.

The two striking aspects of the data presented in table 4 are that health costs

31. Senate Committee on Labor and Public Welfare, Hearings on S. 4323 and S. 3830, National Health Insurance, 91 st Cong. 2d Session, September 23, 1970, p. 200. 
Table 3-Financial Efrects of Three Major Proposals on a

Hypothetical FaMily of Four with an Adjusted Gross Income

of $\$ 6,000$ in 1970 , if the Various Plans had Been in Effect

\begin{tabular}{|c|c|c|c|}
\hline & $\begin{array}{c}\text { Nixon PLAN } \\
\text { (Employer/Employe) }\end{array}$ & Medicredit & $\underset{\text { Kennedy }}{\text { PLAN }}$ \\
\hline $\begin{array}{l}\text { Net After-Tax Income } \\
\text { No Plan and No Services Utilized }\end{array}$ & $\$ 5,562$ & $\$ 5,562$ & $\$ 5,562$ \\
\hline $\begin{array}{l}\text { Assumed Premium or Tax } \\
\text { Assumed Induced Increase in Income Tax } \\
\text { Tax Credit }\end{array}$ & $\begin{array}{r}123 \\
0 \\
0\end{array}$ & $\begin{array}{r}250 \\
100 \\
-230\end{array}$ & $\begin{array}{r}60 \\
100 \\
0\end{array}$ \\
\hline Net Income After Tax, Premium, and Credit & 5,439 & 5,442 & 5,402 \\
\hline $\begin{array}{l}\text { Out-of-Pocket Cost of Services Utilized } \\
\text { Tax Adjustment (Resulting from Additional } \\
\text { Deductions) }\end{array}$ & $\begin{array}{r}1,142 \\
-105\end{array}$ & $\begin{array}{r}108 \\
0\end{array}$ & $\begin{array}{l}0 \\
0\end{array}$ \\
\hline $\begin{array}{l}\text { Net Income After Tax, Premium, Out-of- } \\
\text { Pocket Cost, and Tax Adjustment } \\
\text { Income Reduction by Illness Cost in Dollars } \\
\text { and as Percentage }\end{array}$ & $\begin{array}{l}4,402 \\
1,037(19 \%)\end{array}$ & $\begin{array}{l}5,334 \\
108(2 \%)\end{array}$ & $\begin{array}{r}5,402 \\
0\end{array}$ \\
\hline
\end{tabular}

Assumptions : 1970 tax rates, without surcharge, apply. Services and their prices hypothesized: 45 days of in-patient care $@ \$ 80 /$ day $; 8$ office visits @ $\$ 10 /$ visit; 10 prescriptions $@ \$ 3 / \mathrm{Rx} ; 1$ pair of glasses @ $\$ 12$. These are very conservative assumptions since no consultations or other procedures usually separately charged in the hospital are assumed to have occurred. Deductibles and co-payments calculated according to provisions of relevant Bills. Tax credit under Medicredit is calculated after including $80 \%$ of employer-paid premium of $\$ 200$, for total premium cost of $\$ 450$. Under Nixon plan, premium is assumed to be $\$ 350$, with employe paying $35 \%$. Assumed utilization is well below average for office visits and much above average for hospital care, purposely to indicate financial effects of hypothetical serious illness.

Table 4--Estimates of National Health Expenditures Under Various Proposals, and Under no Plan, After Tax Adjustment, Based on 1970 EXPENDITURes AND TRENDS, FOR FISCAL Year 1974 (in billions of dollars)

\begin{tabular}{|c|c|c|c|c|c|c|c|c|}
\hline \multirow[b]{2}{*}{ Proposed PlaA } & \multirow[b]{2}{*}{ Total } & \multicolumn{4}{|c|}{ Private Sector } & \multicolumn{3}{|c|}{ GOVERNMENT SECTOR } \\
\hline & & Total & $\begin{array}{l}\text { Individual } \\
\text { Direct } \\
\text { Payment }\end{array}$ & $\begin{array}{l}\text { Health } \\
\text { Insur- } \\
\text { ance }\end{array}$ & Other & Total & $\begin{array}{l}\text { State } \\
\text { and } \\
\text { Local }\end{array}$ & Federal \\
\hline Fiscal $1970^{*}$ Actual & $\$ 67.2$ & 40.3 & 21.6 & 15.4 & 3.4 & 26.9 & 7.3 & $19.6 \#$ \\
\hline $\begin{array}{l}\text { 1974, No Plan } \\
\text { 1974, Nixon Plan }\end{array}$ & 105.4 & 62.3 & 32.0 & 26. & 3. & 43.1 & 11.1 & 32,0 \\
\hline $\begin{array}{l}\text { (S. 1623) } \\
\text { 1974, Medicredit }\end{array}$ & $\begin{array}{l}107.2 \\
109.5\end{array}$ & $\begin{array}{l}62.6 \\
61.9\end{array}$ & $\begin{array}{l}28.3 \\
26.5\end{array}$ & $\begin{array}{l}30.4 \\
31.5\end{array}$ & $\begin{array}{l}3.9 \\
3.9\end{array}$ & $\begin{array}{l}44.6 \\
47.6\end{array}$ & $\begin{array}{r}10.0 \\
9.3\end{array}$ & $\begin{array}{l}34.6 \\
38.3\end{array}$ \\
\hline 1974, Kennedy & 113.8 & 15.9 & 11.2 & 1.9 & 2.8 & 97.9 & 6.5 & 91.4 \\
\hline
\end{tabular}

SoUrCe: A Study of National Health Insurance Proposals . . Supplementary Report, Department of Health, Education, and Welfare, July, 1971, pp. 2-9.

* After adjustments for tax deductions and revenue loss.

\# Total federal expenditures are somewhat overstated, since they include war-related and other international expenditures, e.g., in millions by agency: Department of Defense, $\$ 1,900$; Agency for International Development, $\$ 97$; Department of State, $\$ 30$; etc. See "Special Analysis $\mathbf{K}$," $U . S$. Budget, Fiscal 1971. Office of Management and Budget, Table K-15, p. 171. 
are estimated to increase by over $\$ 38$ billion in four years if there is no plan at all, and that the cost differentials among the plans are at most $\$ 6.6$ billion. That the reliability of the estimates is open to question is recognized by their authors. ${ }^{32}$ Assumed changes in cost increases, in utilization rates, in administrative costs, and the like, do not consider adequately that both Medicredit and, to a lesser extent, the Nixon plan would create a financial funnel into the present bottomless pit. ${ }^{33}$ Nor is it clear why, under the Kennedy plan, when basically comprehensive services except, initially, dental care would be provided, individual direct payments would remain at $\$ 11$ billion, with "health insurance" payments at almost $\$ 2$ billion.

The assumption of random estimation error is dangerous and probably incorrect, hence the cost estimates of the various plans may be unevenly biased. Nevertheless, consider that the predicted induced, or additional, costs of the Kennedy plan according to DHEW are shown to be $\$ 8.4$ billion-somewhat at variance with the same administration's publicized estimate of $\$ 77$ billion for the plan. The HEW Report, however, states that "the net additional cost to the Federal taxpayer is therefore estimated at $\$ 59.4$ billion." 34 The $\$ 59.4$ billion is derived by deducting from total program cost (113.8) private sector and state and local government costs $(15.9+6.5)$ to get the federal share of 91.4 ; and then comparing the federal

32. A Study of National Health Insurance Proposals Introduced in the $92 d$ Congress, a Supplementary Report to Congress, Department of HEW, July, 1971, p. 13.

33. See Mike Gorman, "The Impact of $\mathrm{Na}$ tional Health Insurance on Delivery of Health Care," AJPH 61, 5 (May, 1971), pp. 962-971; Elliott A. Krause, "Health and the Politics of Technology," Inquiry 8, 3 (September, 1971), pp. 51-59.

34. A Study (see note 32 ), p. 44. share under the plan with what it would be without one, $\$ 32$ billion. It is reasonable to assume that few if any individuals who do not pay any federal income taxes would be among those who would spend the $\$ 62.3$ billion in direct payments and premiums if there were no plan at all. In fact, the HEW analysis itself shows that private payments would be reduced by $\$ 51.4$ billion under the Kennedy plan. The net additional costs to the federal taxpayers, therefore, would be on the order of $\$ 8$ billion, and not $\$ 59$ billion: private direct payments would be reduced by $\$ 51$ billion and tax payments would increase by some $\$ 59$ billion. For political considerations it might well be important that direct payments would be replaced by tax payments. But this would represent no additional payments. It also would have important income distribution effects by shifting support of the sick poor from the sick middle-income group to a new basis: support of the sick, regardless of income, by the healthy, graduated by income. Depending on the criteria one applies, this may or may not be desirable. But one thing is clear: additional costs to the taxpayer would not be $\$ 77$ billion, nor $\$ 59$ billion. By the HEW estimate itself, they might be $\$ 8$ billion.

It has, however, been argued that, regardless of the accuracy of the cost estimates, no program of major proportions could be instituted because existing medical personnel and facilities would be incapable of meeting the ensuing demands for services. The implications of this argument are made clear by Rashi Fein:

I reject the argument, "Let's wait," for what seems to me to be a most compelling reason. Suppose it is true that the system simply cannot handle more demand. To conclude from that that we should not have national health insurance is to conclude that we should continue to distribute 
the limited supply of medical resources on the basis of ability to pay. I believe that this is inequitable and indefensible.

Should not the limited supply be available to all Americans-not only to those who are in fortunate enough economic circumstances to be able to pay the market price and compete against their neighbors? Those who say we cannot meet the demands must recognize that means we are rationing the supply, and $\mathrm{I}$ do not believe medical care should be rationed on the basis of ability to pay. ${ }^{35}$

The Nixon and Medicredit plans, then, by rather similar marginalist approaches, would create a federally mandated national voluntary private system to finance some of the costs of medical care. Both plans would be relatively more beneficial to the middle-income groups. Both would treat the poor differently; each would reinforce the double standard of care: one for the rich, a fraction for the poor. By providing for the ill-defined HMO, the Nixon plan would encourage some change in the supply system. Medicredit would not alter the system but would reinforce those very characteristics which have led to the ubiquitous cries of "crisis." Of the other plans we have not discussed, the Scott/Percy, Burleson, and Pell/Mondale Bills are similar in basic respects to Medicredit, except for their financing mechanism. In its target benefits, the Burleson bill (also known as the Aetna bill, after its major supporter) is even less complete than the Nixon bill. It could truly be called a "Buffalo Bill":

It reminds me of the old Buffalo policy. There are deductibles, co-insurance clauses, exclusions, loopholes and gaps-so much fine print that it resembles the policy that covers you only when you are run over by

35. Hearings, (see note 31 ), Part 2, September 24,1970, p. 372 .

36. Leonard Woodcock, quoted in The New York Times, Wednesday, April 28, 1971.
TABLE 5-Health Insurance Benefits, HOGAN BILI

\begin{tabular}{lcc}
\hline & \multicolumn{2}{c}{ Calendar Year Deductible } \\
\cline { 2 - 3 } $\begin{array}{c}\text { Annuai. Income, } \\
\text { Family of Four }\end{array}$ & $\begin{array}{c}\text { In dollar } \\
\text { amount }\end{array}$ & $\begin{array}{c}\text { As percentage } \\
\text { of income }\end{array}$ \\
\hline$\$ 4,000$ or below & None & None \\
5,000 & $\$ 500$ & 10 \\
6,000 & 1,500 & 25 \\
8,000 & 3,500 & 44 \\
10,000 & 5,500 & 55 \\
15,000 & 10,500 & 70 \\
25,000 & 22,500 & 90 \\
\hline
\end{tabular}

a herd of Buffalo in downtown Detroitat high noon. ${ }^{36}$

Taking a systematic approach to the intertwined problems of health care, the Kennedy plan would reorganize the system by providing for the evolution of publicly accountable, publicly financed, publicly regulated comprehensive private systems of care for all, regardless of income. Based on a fairly progressive financial mechanism, it would re-allocate resources over time to alter the present maldistribution, and make care accessible to all. Ameriplan, not yet in legislative form, would be somewhat similar to the Kennedy plan in many respects, with its emphasis on the health care corporation, while enshrining the hospital as not only the technical but also the legal and institutional fulcrum of care. The Javits bill falls somewhat in the middle between the Nixon and the Kennedy plans. By expanding Medicare, it would cover all persons but it would also retain all the Buffalo characteristics: co-payments, deductibles, limitations on service, exclusions, delays.

We have not discussed any of the socalled catastrophic-illness insurance plans. An example, perhaps, will demonstrate why. The Hogan bill, H.R. 817 , is designed to provide insurance against the costs of catastrophic illness. The benefits are a function of family income, that is, they are reduced by a deductible to be paid by the family. 
For a family of four, H.R. 817 establishes the deductible schedule found in table 5. This bill appears to be designed to achieve complete equality among the seriously ill: all incomes would be reduced to $\$ 4,500$ - except at the $\$ 25,000$ level. There they would be reduced to $\$ 2,500$.

\section{ConClusion}

There are many specific issues involved in the choice of a plan; some we have discussed and some we have not. Important among these issues are the methods to increase the availability and accessibility of resources responsive to patient needs, and the means of channeling patients into and within the system.

We have demonstrated that there are vast differences among the present plans and that the choice is not between one or another method of financing. The choice is between systems for providing useful medical services.

If after sixty years the idea of national health insurance is not to be stillborn once again, the challenges are clear:

1. Elimination of barriers to access to treatment, be they caused by individual financial limitations, systemic disorganization, or resource shortages;

2. Incorporation into the mainstream of medicine modern technological and managerial advances while rekindling the humanistic idea that a patient is not a set of organ systems, but a person in a social system;

3. Development of mechanisms of public accountability to assure not only the quality of care given but also that all those who may benefit from care in fact receive it;

4. Achievement of these ends within the pluralistic American framework of balanced power at reasonable cost.

Although the Kennedy bill represents a good first step, none of the proposals for NHI meet these objectives.

The basic question is not "What will it cost?" The basic question is "What is it we want?" If it is high quality medical care for all Americans regardless of income, color, social class, or location, the challenge is to devise a workable system to provide that at the lowest cost.

Just as our National Government has moved to provide equal opportunity in areas such as education, employment, and voting, so we must now work to expand the opportunity for all our citizens to obtain a decent standard of medical care. We must do all we can to remove any racial, economic, social, or geographic barriers which now prevent any of our citizens from obtaining adequate health care protection. For without good health, no man can fully utilize his other opportunities. ${ }^{37}$

37. President Nixon's Health-A Message from the President of the United States Relative to Building a National Health Strategy, 92d Congress, 1st Session, House Document No. 92-49, February 18, 1971, p. 2. 


\section{APPENDIX}

National Health Insurance Proposals and Related Proposals Introduced in the 92nd Congress, and Other Proposals

\begin{tabular}{|c|c|c|c|}
\hline BILL NUMBER & SPONSOR & $\begin{array}{c}\text { DATE } \\
\text { INTRODUCED }\end{array}$ & CHARACTERISTICS \\
\hline $\begin{array}{l}\text { S. } 3 \\
\text { Identical bills: } \\
\text { H.R. } 22 \\
\text { H.R. } 23 \\
\text { H.R. } 2162 \\
\text { H.R. } 2163 \\
\text { H.R. } 2478 \\
\text { H.R. } 4124 \\
\text { H.R. } 4141 \\
\text { H.R. } 5007 \\
\text { H.R. } 5246 \\
\text { H.R. } 7339\end{array}$ & $\begin{array}{l}\text { Kennedy et al. } \\
\text { Griffiths et al. } \\
\text { Griffiths et al. } \\
\text { Griffiths et al. } \\
\text { Griffiths et al. } \\
\text { Helstoski } \\
\text { Griffiths et al. } \\
\text { Kee } \\
\text { Nedzi } \\
\text { Minish } \\
\text { Griffiths et al. }\end{array}$ & $\begin{array}{l}1-25-71 \\
1-22-71 \\
1-22-71 \\
1-25-71 \\
1-25-71 \\
1-29-71 \\
2-10-71 \\
2-10-71 \\
2-25-71 \\
3-1-71 \\
4-7-71\end{array}$ & $\begin{array}{l}\text { TCC; no deductibles or co- } \\
\text { payment; basic reliance on } \\
\text { prepaid capitation; essentially } \\
\text { replaces most current pro- } \\
\text { grams; would eliminate pri- } \\
\text { vate carriers; financing: all } \\
\text { public by mixture of general } \\
\text { and earmarked taxes. }\end{array}$ \\
\hline $\begin{array}{l}\text { H.R. } 48 \\
\text { Identical bill: } \\
\text { H.R. } 211\end{array}$ & $\begin{array}{l}\text { Dingell } \\
\text { Matsunaga }\end{array}$ & $\begin{array}{l}1-22-71 \\
1-22-71\end{array}$ & $\begin{array}{l}\text { In many respects similar to } \mathrm{S} .3 \text {, } \\
\text { but administratively decen- } \\
\text { tralized to states. }\end{array}$ \\
\hline $\begin{array}{l}\text { H.R. } 177 \\
\text { Identical bills: } \\
\text { H.R. } 178 \\
\text { H.R. } 576 \\
\text { H.R. } 3847\end{array}$ & $\begin{array}{l}\text { Hall (Mo.) et al. } \\
\text { Hall (Mo.) et al. } \\
\text { Ashbrook } \\
\text { Teague (Calif.) }\end{array}$ & $\begin{array}{l}1-22-71 \\
1-22-71 \\
1-25-71 \\
2-8-71\end{array}$ & $\begin{array}{l}\text { "Catastrophic" coverage based } \\
\text { on income; most limited of all } \\
\text { proposals; basically privately } \\
\text { financed; no change in system. }\end{array}$ \\
\hline $\begin{array}{l}\text { H.R. } 817 \\
\text { Identical bills: } \\
\text { S. } 191 \\
\text { H.R. } 4133 \\
\text { H.R. } 6396\end{array}$ & $\begin{array}{l}\text { Hogan et al. } \\
\text { Boggs et al. } \\
\text { Hogan et al. } \\
\text { Roush }\end{array}$ & $\begin{array}{l}1-22-71 \\
1-26-71 \\
2-10-71 \\
3-18-71\end{array}$ & $\begin{array}{l}\text { Same comments apply as for } \\
\text { H.R. } 177 \text {. }\end{array}$ \\
\hline $\begin{array}{l}\text { H.R. } 1283 \\
\text { Identical bill: } \\
\quad \text { H.R. } 3167\end{array}$ & $\begin{array}{l}\text { Fisher } \\
\text { Tiernan }\end{array}$ & $\begin{array}{l}1-22-71 \\
2-1-71\end{array}$ & $\begin{array}{l}\text { More limited version of Medi- } \\
\text { credit. }\end{array}$ \\
\hline$S .703$ & Pell/Mondale & $2-10-71$ & $\begin{array}{l}\text { LCV; mixed public/private fi- } \\
\text { nancing; benefits very limited, } \\
\text { and based on income. }\end{array}$ \\
\hline $\begin{array}{l}\text { H.R. } 4349 \\
\text { Identical bills : } \\
\text { H.R. } 4980 \\
\text { H.R. } 5227 \\
\text { H.R. } 5984 \\
\text { S. } 1490\end{array}$ & $\begin{array}{l}\text { Burleson (Tex.) et al. } \\
\text { Jarman } \\
\text { Halpern } \\
\text { Monagan } \\
\text { McIntyre et al. }\end{array}$ & $\begin{array}{l}2-17-71 \\
2-25-71 \\
3-1-71 \\
3-11-71 \\
4-5-71\end{array}$ & $\begin{array}{l}\text { LCV; } 3 \text { different plans; complete } \\
\text { reliance on private carriers; } \\
\text { premiums based on income; } \\
\text { benefits would be enlarged } \\
\text { over time; little or no change } \\
\text { in system; some federal } \\
\text { funding. }\end{array}$ \\
\hline S. 836 & Javits & $2-18-71$ & $\begin{array}{l}\text { LCV; expansion of Medicare } \\
\text { over time; many deductibles, } \\
\text { and co-payment; maintains } \\
\text { current private/public mix; } \\
\text { little effect on system. }\end{array}$ \\
\hline $\begin{array}{l}\text { H.R. } 4960 \\
\text { Identical bills : } \\
\text { H.R. } 4901 \\
\text { H.R. } 4961 \\
\text { H.R. } 4962 \\
\text { H.R. } 4963 \\
\text { H.R. } 5487 \\
\text { H.R. } 5711\end{array}$ & $\begin{array}{l}\text { Fulton (Tenn.)/Broyhill (Va.) et al. } \\
\text { Abernethy } \\
\text { Fulton/Broyhill et al. } \\
\text { Fulton/Broyhill et al. } \\
\text { Fulton/Broyhill et al. } \\
\text { Tiernan } \\
\text { Quillen }\end{array}$ & $\begin{array}{l}2-25-71 \\
2-25-71 \\
2-25-71 \\
2-25-71 \\
2-25-71 \\
3-3-71 \\
3-8-71\end{array}$ & $\begin{array}{l}\text { LCV; Medicredit; } 2 \text { plans; many } \\
\text { deductibles, and co-payment; } \\
\text { benefits broad with few ex- } \\
\text { ceptions; retains Medicare; } \\
\text { financed through tax credits } \\
\text { and federal funds for those } \\
\text { without tax liability; no } \\
\text { changes in current system. }\end{array}$ \\
\hline
\end{tabular}




\begin{tabular}{|c|c|c|c|}
\hline Bill Number & SPONSOR & $\begin{array}{c}\text { DATE } \\
\text { INTRODUCED }\end{array}$ & Characteristics \\
\hline $\begin{array}{l}\text { H.R. } 6372 \\
\text { H.R. } 7124 \\
\text { S. } 987\end{array}$ & $\begin{array}{l}\text { Fulton (Tenn.) et al. } \\
\text { Whitten } \\
\text { Hansen et al. }\end{array}$ & $\begin{array}{l}3-18-71 \\
4-1-71 \\
2-25-71\end{array}$ & \\
\hline S. 1376 & Long et al. & $3-24-71$ & $\begin{array}{l}\text { LCV; "Catastrophic"; operated } \\
\text { through Medicare. }\end{array}$ \\
\hline S. 1598 & Scolt/Percy & $4-21-71$ & $\begin{array}{l}2 \text { separate plans; private/public } \\
\text { mix; reliance on carriers; co- } \\
\text { payments and deductibles } \\
\text { based on income; little change } \\
\text { in system. }\end{array}$ \\
\hline $\begin{array}{l}S .1623 \\
\text { Identical bill : } \\
\text { H.R. } 7741\end{array}$ & $\begin{array}{l}\text { Bennett et al. } \\
\text { Byrnes et al. }\end{array}$ & $\begin{array}{l}4-22-71 \\
4-27-71\end{array}$ & $\begin{array}{l}\text { LCV; Nixon plan; } 2 \text { separate } \\
\text { plans; mostly private financ- } \\
\text { ing; co-payments and de- } \\
\text { ductibles; little change in } \\
\text { system. }\end{array}$ \\
\hline
\end{tabular}

Note: TCC $=$ Total, Comprehensive, Compulsory $; \mathrm{LCV}=$ Limited, Categorical, Voluntary.

\section{Other Proposed Plans}

Major Risk Insurance: Martin S. Feldstein, “A New Approach to National Health Insurance," The Public Interest, Spring, 1971, pp. 93-105.

Variable Subsidy Insurance: Mark V. Pauly, National Health Insurance: An Analysis, American Enterprise Institute for Public Policy Research, Special Analysis 8, August, 1971.

Tax Credit Plan: Charles W. Baird, "A Proposal for Financing the Purchase of Health Services," The Journal of Human Resources 5, 1 (Winter, 1970), pp. 89-105.

Postpayment Plan: R. D. Eilers, "Postpayment Medical Expense Coverage: A Proposed Salvation for Insured and Insurer," Blue Cross Reports, Research Series 1, September, 1969.

Ameriplan: "Ameriplan-A Proposal for the Delivery and Financing of Health Services in the United States," Report of a Special Committee on the Provision of Health Services, American Hospital Association, Chicago, Illinois, 1970. 